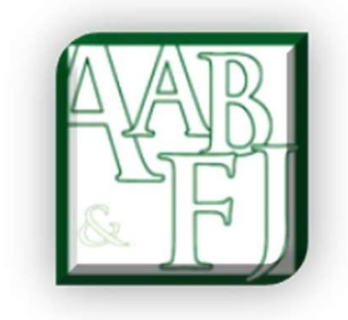

\title{
AABFJ Moving Towards History Papers
}

Ciorstan Smark ${ }^{1}$ and Monir Mir ${ }^{2}$

This issue of AABFJ brings together six articles. Two of these articles are from a Forensic Accounting area. Articles from Finance include two studies from Asian markets. From Accounting, we have a discussion on audit reports in Australia and a reflection close to most of our hearts about the challenges of teaching Accounting During the Coved-19 pandemic.

Prabowo (2021) discusses a new development in undergraduate forensic accounting programs in Indonesia. This article will be of interest to forensic accounting educators and program directors internationally. Fargher (2021) looks at the topic of "control" over assets from an Australian Family Law perspective. This article will be of interest to those involved in family law disputes.

In the area of Emerging Markets, Paisarn, Chancharat and Chancharat (2021) investigate trading behaviour amongst Thai retail investors for investor bias. DasGupta and Singh (2021) examine firm risk and managerial risk-taking in the context of India.

Related to Accounting, Deng, Bowrey and Jones (2021) explore the impact of a change in regulations affecting audit reports in Australia using Archer (1995) 's morphogenetic approach. Finally, Djajadikerta et al. (2021) present the Coved-19 teaching experiences of Accounting Academics in Australia, Malaysia and Indonesia.

On housekeeping matters, we have received several positive responses to our suggestion floated in Smark and Mir (2020) of having a more prominent history stream of accounting, finance and economic history articles to $\mathrm{AABFJ}$. If you are interested in reviewing history articles for AABFJ, please email your CV to AABFJournal@gmail.com. History papers have been published in AABFJ for many years. For example, in taxation history, Passant (2016; 2017; 2018); Bisman (2007) and Ryan (2014) in Accounting. We look forward to adding to our history stream.

\section{References}

Archer, M.S. (1995) Realist Social Theory: The Morphogenetic Approach. Cambridge, MA: Cambridge University Press. https://doi.org/10.1017/CBO9780511557675

Bisman, Jayne, Accounting concepts in the construction of social status and privilege: a microhistorical study of an early Australian convict, Australasian Accounting, Business and Finance Journal, 1(4), 2007, 1-15. doi:10.14453/aabfj.v1i4.1 http://dx.doi.org/10.14453/aabfj.v1i4.1

\footnotetext{
${ }^{1}$ University of Wollongong, Australia

${ }^{2}$ University of Canberra, Australia
} 
DasGupta, Ranjan and Singh, Rashmi, Antecedents of Firm's Risk-play - A Structural Equation Modeling Approach in an Emerging Market Context, Australasian Accounting, Business and Finance Journal, 15(2), 2021, 56-82. doi:10.14453/aabfj.v15i2.5 http://dx.doi.org/10.14453/aabfj.v15i2.5

Deng, Ying; Bowrey, Graham; and Jones, Greg, Exploring Changing Requirements of Financial Statement Audit Reports via a Morphogenetic Approach, Australasian Accounting, Business and Finance Journal, 15(2), 2021, 38-55. doi:10.14453/aabfj.v15i2.4 http://dx.doi.org/10.14453/aabfj.v15i2.4

Djajadikerta, Hadrian Geri; Trireksani, Terri; Ong, Tricia; Roni, Saiyidi Mat; Kazemian, Soheil; Zhang, Junru; Noor, Abd Halim Mohd; Ismail, Shafinar; Ahmad, Mohamad Azmi Nias; Azhar, Zubir; Shahbudin, Amirul Shah Md; Maradona, Agus Fredy; Yanto, Heri; and Wahyuningrum, Indah Fajarini Sri, Australian, Malaysian and Indonesian Accounting Academics' Teaching Experiences During the COVID-19 Pandemic, Australasian Accounting, Business and Finance Journal, 15(2), 2021, 103-113.

doi: $10.14453 /$ aabfj.v15i2.7 http://dx.doi.org/10.14453/aabfj.v15i2.7

Fargher, Ian, Valuation and Service Trusts, Australasian Accounting, Business and Finance Journal, 15(2), 2021, 83-102. doi:10.14453/aabfj.v15i2.6

http://dx.doi.org/10.14453/aabfj.v15i2.6

Paisarn, Wilaiporn; Chancharat, Nongnit; and Chancharat, Surachai, Factors Influencing Retail Investors' Trading Behaviour in the Thai Stock Market, Australasian Accounting, Business and Finance Journal, 15(2), 2021, 26-37. doi:10.14453/aabfj.v15i2.3 http://dx.doi.org/10.14453/aabfj.v15i2.3

Passant, John, Historical Note: The History of Taxation is Written in Letters of Blood and Fire, Australasian Accounting, Business and Finance Journal, 10(2), 2016, 93-101. doi:10.14453/aabfj.v10i2.6 http://dx.doi.org/10.14453/aabfj.v10i2.6

Passant, John, Taxation and the American Revolution, Australasian Accounting, Business and Finance Journal, 11(3), 2017, 20-29. doi:10.14453/aabfj.v11i3.3 http://dx.doi.org/10.14453/aabfj.v11i3.3

Passant, John, Tax and the Forgotten Classes: from the Magna Carta to the English Revolution, Australasian Accounting, Business and Finance Journal, 10(3), 2016, 67-88. doi:10.14453/aabfj.v10i3.5 http://dx.doi.org/10.14453/aabfj.v10i3.5

Prabowo, Hendi Yogi, Undergraduate Forensic Accounting Education in Indonesia: Initiating a ReInvention, Australasian Accounting, Business and Finance Journal, 15(2), 2021, 3-25. doi:10.14453/aabfj.v15i2.2 http://dx.doi.org/10.14453/aabfj.v15i2.2

Ryan, John, Historical Note: Did double-entry bookkeeping contribute to economic development, specifically the introduction of capitalism?, Australasian Accounting, Business and Finance Journal, 8(3), 2014, 85-97. doi:10.14453/aabfj.v8i3.8 http://dx.doi.org/10.14453/aabfj.v8i3.8

Smark, Ciorstan and Mir, Monir, Editorial Volume 14 Issue 5, Australasian Accounting, Business and Finance Journal, 14(5), 2020, 1-2. doi:10.14453/aabfj.v14i5.1 http://dx.doi.org/10.14453/aabfj.v14i5.1 